\title{
The Influence of pH on the Forms of Cadmium in Four West Australian Soils
}

\author{
S. S. Mann and G. S. P. Ritchie
}

\begin{abstract}
The forms of cadmium in soils affect its uptake by plants and hence its potential toxicity to animals and humans. We studied the effect of $\mathrm{pH}$ on the forms of native and added $\mathrm{Cd}$ in four West Australian soils which differed in their clay, hydrous oxide and organic matter content. The forms of $\mathrm{Cd}$ were extracted sequentially by $\mathrm{KCl}, \mathrm{BaCl}_{2}, \mathrm{NaOCl}$, ammonium oxalate and concentrated acids.

The majority of $\mathrm{Cd}$ applied to a sandy soil was found in the soluble ( $\mathrm{KCl}$ ) and the exchangeable $\left(\mathrm{BaCl}_{2}\right.$ ) forms at all $\mathrm{pH}$ values. In the siliceous sand, the proportion of the $\mathrm{Cd}$ present in the exchangeable form increased as the soil solution $\mathrm{pH}$ increased. However, in the peaty sand, the opposite trend was observed; at $\mathrm{pH} 5$, approximately $50 \%$ of the $\mathrm{Cd}$ was found in the exchangeable form, while at higher $\mathrm{pH}$ values, $>60 \%$ was bound to organic matter and $20 \%$ was in the soluble form. In soils in which the main adsorption surface was dominated by hydrous oxides (mainly goethite), 50-70\% of the $\mathrm{Cd}$ was extracted as bound to oxides and as the residual fraction at $\mathrm{pH} \leq 5$. At $\mathrm{pH}$ values $>5$, the majority (90\%) of it was extracted in these forms. Soils, containing clay (mainly kaolinite) as the major adsorbent, retained $\mathrm{Cd}$ mainly in exchangeable form at all $\mathrm{pH}$ values and at all the rates of $\mathrm{Cd}$ application. At $\mathrm{pH}>5$, however, some of the $\mathrm{Cd}$ was also found in the residual form and bound to organic matter.

This work has shown that the form of added Cd in a soil cannot be elucidated by considering the major adsorbing component alone. It is also necessary to know the $\mathrm{pH}$, the presence of other adsorbing surfaces and the rates of applied $\mathrm{Cd}$.
\end{abstract}

\section{Introduction}

Toxic concentrations of cadmium (Cd) in humans can occur from consumption of plant or animal products grown on soils in which $\mathrm{Cd}$ has accumulated. Phosphatic fertilizers contain varying amounts of $\mathrm{Cd}$ as an impurity depending on the source of the rock phosphates used (Williams and David 1973). Superphosphate is the most commonly used fertilizer in Australia and nearly $50 \%$ of its total Cd content (18-91 $\mu \mathrm{g} \mathrm{g}^{-1}$ ) is water-soluble (Mann 1989). The uptake of $\mathrm{Cd}$ by plants depends on both soil and plant factors and is influenced by management practices. It has been shown that the $\mathrm{Cd}$ content of plants increases with the amount of superphosphate applied (Williams and David 1973) and with a decrease in soil pH (Williams and David 1977; Tiller 1988; Whitten and Ritchie 1991). Since plants take up $\mathrm{Cd}$ from the soil solution, any factor that affects its concentration 
in solution and the rate of replenishment of the solution concentration (after it has been depleted) will affect the extent of Cd uptake.

Cadmium may exist in the soil in several different forms. When Cd enters the soil it may remain in the soil solution as a free cation or complexed with inorganic or organic ligands (Tills and Alloway 1983), it may adsorb onto exchange sites on clays, hydrous oxides and organic matter (Brown 1954; Sposito and Page 1985) or it may be specifically adsorbed by oxides and hydroxides of $\mathrm{Fe}, \mathrm{Al}$ and Mn (Tiller et al. 1984). Cadmium may be entrapped following diffusion into goethite, Mn oxides and other minerals present in soils (Brummer et al. 1988). The reactions of $\mathrm{Cd}$ with each soil component will depend upon a number of factors, e.g. soil type, $\mathrm{pH}$, rainfall, temperature, time, management practices and the source of applied Cd. For example, specific adsorption of $\mathrm{Cd}$ onto synthetic goethites and onto the edges of clay minerals is $\mathrm{pH}$ dependent (e.g. Forbes et al. 1976; Tiller et al. 1984; Brummer et al. 1988). However, understanding the factors that affect the amount of only one possible form of $\mathrm{Cd}$ in the soil is not necessarily going to help predict its availability to plants.

The amount of $\mathrm{Cd}$ in any one form in the soil could also depend on the extent of saturation of a particular type of site. This could be an important factor for soils which are fertilized regularly with large amounts of Cd-containing, phosphatic fertilizers such as in horticultural enterprises. Saturation of sites that adsorb Cd strongly (and hence are in equilibrium with a low soluble Cd activity) could lead to further added Cd being less strongly adsorbed and hence more readily available for release into the soil solution and subsequent uptake by plants. Therefore, it is important to understand the distribution of Cd into different forms in the soil because each form will have a different ability to release $\mathrm{Cd}$ into the soil solution. In turn, we need to understand the relative importance of exterior factors in changing the equilibrium between each solid form and the soil solution.

We studied the effect of $\mathrm{pH}$ on the forms of native and added $\mathrm{Cd}$ in four West Australian soils which differed in their clay, hydrous oxide and organic matter content. The forms of $\mathrm{Cd}$ were extracted sequentially by $\mathrm{KCl}, \mathrm{BaCl}_{2}$, $\mathrm{NaOCl}$, ammonium oxalate and concentrated acids. The amounts of $\mathrm{Cd}$ added were similar to the amounts which would be added over a 20 year period to soils fertilized with low to high rates of superphosphate and which are commonly used in broad-acre agriculture and intensive horticulture. In addition, Cd extracted by EDTA (used as an estimate of labile Cd; Fujii and Corey 1986) was compared with $\mathrm{Cd}$ extracted by each solution in the sequential extraction scheme.

The sequential extraction scheme was developed to attempt to distinguish between soluble $(\mathrm{KCl})$, exchangeable $\left(\mathrm{BaCl}_{2}\right)$, organically bound $(\mathrm{NaOCl})$, specifically adsorbed (ammonium oxalate solution) and residual $\mathrm{Cd}$ (concentrated acids) which were considered to be the major forms in these non-calcareous soil types which are low in $\mathrm{Mn}$. It is similar to schemes developed for other trace elements by McLaren and Crawford (1973), Tessier et al. (1979) and Shuman (1985).

\section{Materials and Methods}

\section{Soils}

Soil was collected from a yellow earth (Soil 1 ; Northcote classification: Uc $1 \cdot 22$; Northcote 1974), lateritic podzolic (Soil 2; Uc5.51), peaty sand (Soil 3; Uc 2.33) and siliceous sand 
Table 1. Some properties of the soils used

\begin{tabular}{|c|c|c|c|c|c|c|c|c|c|c|c|c|}
\hline \multirow{3}{*}{ Soil } & \multirow{3}{*}{$\begin{array}{l}\begin{array}{c}\text { Northcote } \\
\text { classification }\end{array} \\
\text { Gn } 1 \cdot 22\end{array}$} & \multirow{3}{*}{$\frac{\begin{array}{c}\text { Total Cd } \\
\left(\mu \mathrm{g} \mathrm{g}^{-1}\right)\end{array}}{0.07}$} & \multirow{3}{*}{$\frac{\mathrm{pH}^{\mathrm{A}}}{5 \cdot 40}$} & \multirow{3}{*}{$\frac{\begin{array}{c}\text { Org. } \mathrm{C} \\
(\%)\end{array}}{0.31}$} & \multirow{3}{*}{$\frac{\begin{array}{c}\mathrm{EC} \\
\left(\mu \mathrm{S} \mathrm{cm}^{-1}\right)\end{array}}{71}$} & \multirow{3}{*}{$\begin{array}{l}\mathrm{FC}^{\mathrm{B}} \\
(\%)\end{array}$} & \multirow{2}{*}{\multicolumn{2}{|c|}{$\begin{array}{c}\mathrm{Al}^{\mathrm{C}} \\
\left(\mu \mathrm{g} \mathrm{g}^{-1}\right) \\
\mathrm{Fe}^{\mathrm{C}}\end{array}$}} & \multicolumn{3}{|c|}{ Size fraction (\%) } & \multirow{3}{*}{$\begin{array}{c}\begin{array}{c}\text { Dominant } \\
\text { minerals }\end{array} \\
\begin{array}{l}\text { goethite \& } \\
\text { kaolinite }\end{array}\end{array}$} \\
\hline & & & & & & & & & Sand & Silt & Clay & \\
\hline & & & & & & & $84 \cdot 4$ & 1498 & 84 & $2 \cdot 5$ & $7 \cdot 8$ & \\
\hline Lateritic podzolic & $\mathrm{Uc} 5 \cdot 51$ & $0 \cdot 14$ & $3 \cdot 74$ & $0 \cdot 30$ & 372 & 20 & $10 \cdot 0$ & 292 & 89 & 0.8 & $9 \cdot 9$ & kaolinite \\
\hline Peaty sand & $\mathrm{Uc} 2 \cdot 33$ & $<0.01$ & $4 \cdot 04$ & $3 \cdot 14$ & 35 & 15 & $32 \cdot 6$ & 52 & 96 & $1 \cdot 0$ & $2 \cdot 5$ & quartz \\
\hline Siliceous sand & $\mathrm{Uc} 2 \cdot 22$ & $<0.01$ & $5 \cdot 75$ & $0 \cdot 12$ & 15 & 10 & $6 \cdot 4$ & $5 \cdot 5$ & 99 & 0.4 & $<0 \cdot 1$ & quartz \\
\hline
\end{tabular}

A Soil solution. $\quad{ }^{\mathrm{B}}$ Field capacity. ${ }^{\mathrm{C}}$ Acid ammonium oxalate extraction.

Table 2. Detailed sequential extraction scheme used for extraction of forms of Cd from soils

\begin{tabular}{|c|c|c|c|c|}
\hline $\begin{array}{c}\text { Extraction } \\
\text { No. }\end{array}$ & $\begin{array}{l}\text { Forms } \\
\text { of } \mathrm{Cd}\end{array}$ & Extractant & $\begin{array}{l}\text { Ratio of } \\
\text { soil/soln }\end{array}$ & Procedure \\
\hline 1 & soluble & $0.005 \mathrm{M} \mathrm{KCl}$ & $1: 5$ & Shake for $30 \mathrm{~min}$ \\
\hline 2 & exchangeable & $0 \cdot 1 \mathrm{M} \mathrm{BaCl}_{2}$ & $1: 10$ & Shake residue from (1) for $17 \mathrm{~h}$ \\
\hline 3 & bound to organic matter & $5 \cdot 3 \% \mathrm{NaOCl}(\mathrm{pH} \approx 8 \cdot 5)$ & $1: 2$ & $\begin{array}{l}\text { Residue from (2) placed in water bath at } 90^{\circ} \mathrm{C} \\
\text { for } 15 \text { min. Repeat two more times agitating in } \\
\text { between. Combine the three extracts }\end{array}$ \\
\hline 4 & $\begin{array}{l}\text { bound to } \\
\text { oxides/clays }\end{array}$ & $\begin{array}{l}0.2 \mathrm{M} \text { amm. ox. } \\
0 \cdot 2 \mathrm{M} \text { oxalic acid } \\
0 \cdot 1 \mathrm{M} \text { ascorbic } \\
\text { acid }(\mathrm{pH} \approx 3)\end{array}$ & $1: 40$ & Residue from (3) shaken in dark for $4 \mathrm{~h}$ \\
\hline 5 & residual & $\begin{array}{l}\text { concentrated } \\
\mathrm{HNO}_{3} / \mathrm{HClO}_{4} / \mathrm{HF} \\
\text { and } 6 \mathrm{M} \mathrm{HCl} \text { acids }\end{array}$ & - & $\begin{array}{l}\text { Transfer residue from (4) to a teflon beaker with } \\
\text { double-deionized water washings, dry on hot plate. } \\
\text { Add } 3 \mathrm{~mL} \mathrm{HNO}_{3} \text { and } 0.5 \mathrm{~mL} \mathrm{HClO}_{4} \text { and heat to } \\
\text { dryness. Add } 5 \mathrm{~mL} \mathrm{HF} \text { and } 0.5 \mathrm{~mL} \mathrm{HClO}_{4} \text {, heat } \\
\text { to dryness and repeat } \mathrm{HF} / \mathrm{HClO}_{4} \text { treatment. Add } \\
5 \mathrm{~mL} 6 \mathrm{M} \mathrm{HCl} \text { and } 5 \mathrm{~mL} \text { double-deionized water } \\
\text { and heat for } 10 \mathrm{~min} \text {. Make volume to } 10 \mathrm{~mL} \text { with } \\
\text { double-deionized water }\end{array}$ \\
\hline
\end{tabular}


(Soil 4; Uc $2 \cdot 22$ ). Soils 1 and 2 were collected from a depth of $25-45 \mathrm{~cm}$ whereas soils 3 and 4 were collected from the $0-20 \mathrm{~cm}$ layer after removing the vegetation and clearing the debris. The soils were air-dried and ground to pass through a $2 \mathrm{~mm}$ sieve. Some properties of the soils are given in Table 1.

\section{Adjustment of Soil Solution $p H$}

The $\mathrm{pH}$ of an aliquot of each soil was adjusted to four different values $(4 \cdot 0,5 \cdot 0,6 \cdot 0$ and $7 \cdot 0$ ) by adding different concentrations of $\mathrm{HCl}$ and $\mathrm{KOH}$ in a volume equivalent to the field capacity of each soil and then incubating the soil samples for 1 week at $40 \pm 1^{\circ} \mathrm{C}$. The moisture in the incubated samples was maintained to field capacity throughout the incubation period. The concentrations of $\mathrm{HCl}$ and $\mathrm{KOH}$ were calculated from the buffer curves (meq $\mathrm{H}^{+}$and $\mathrm{OH}^{-}$per $100 \mathrm{~g}$ soil) for each individual soil. Preliminary experiments indicated that the $\mathrm{pH}$ after incubation varied by $\leq \pm 0.1$ unit if this procedure was used. The soils after incubation were centrifuged and the $\mathrm{pH}$ of the drained solution was measured.

\section{Addition of Cadmium}

Cadmium was applied as $\mathrm{Cd}\left(\mathrm{NO}_{3}\right)_{2}$ at $0,0.8,3.2$ and $10 \cdot 0 \mu \mathrm{g} \mathrm{g}^{-1}$ soil in a volume of double-deionized water sufficient to bring $200 \mathrm{~g}$ soil to field capacity. Each subsample was incubated at $40 \pm 1^{\circ} \mathrm{C}$ for 8 days and then frozen at $-20 \pm 1^{\circ} \mathrm{C}$ until analyses were carried out.

\section{Sequential Extraction of Chemical Forms of Cadmium}

Samples to be extracted for different forms of Cd were first thawed to room temperature and were mixed thoroughly. Wet soil, equivalent to $1 \mathrm{~g}$ dry soil, was weighed into $50 \mathrm{~mL}$ polypropylene centrifuge vials in triplicate. The different forms of $\mathrm{Cd}$ were then extracted by the sequential extraction scheme described in Table 2. After each soil sample was shaken with a particular solution, the samples were centrifuged at $2000 \mathrm{rpm}$ and the supernatant was filtered $(<0.45 \mu \mathrm{m})$ and stored at $4^{\circ} \mathrm{C}$ until analysis. The soil residue was washed with double-deionized water before adding the next extracting solution to decrease contamination of $\mathrm{Cd}$ in the following extract.

\section{Cadmium Analysis}

Cadmium in all the extracts was analysed by flame atomic absorption spectrophotometry (AAS) on a Perkin-Elmer 5000 atomic absorption spectrophotometer using background correction to eliminate interference from non-atomic absorption.

Cadmium in ammonium oxalate and $\mathrm{NaOCl}$ extracts was analysed by using a teflon cup to aspirate the extracts and avoid blockage of the nebulizer (Simmons and Plues-Foster 1977).

Cadmium in $\mathrm{KCl}, \mathrm{BaCl}_{2}$ and $\mathrm{NaOCl}$ extracts which was below the detection limit of the flame was complexed with ammonium pyrrolidine dithiocarbamate (APDC) and extracted into 4-methylpentan-2 one (Syn. methyl isobutyl ketone, MIBK) according to the method of Dudas (1974) in order to eliminate potential matrix effects during analysis. The MIBK extract was then analysed for Cd by furnace AAS using pyrolytically coated platform fitted graphite tubes in a Perkin-Elmer HGA 500 graphite furnace coupled to a Perkin-Elmer 5000 with background correction. The temperature program used for the determination of $\mathrm{Cd}$ is given in Table 3 .

Table 3. Temperature program for Cd determination by graphite furnace

\begin{tabular}{lccccc}
\hline $\begin{array}{c}\text { Step } \\
\text { No. }\end{array}$ & $\begin{array}{c}\text { Furnace } \\
\text { temperature } \\
\left({ }^{\circ} \mathrm{C}\right)\end{array}$ & Ramp & $\begin{array}{c}\text { Time } \\
\text { Hold }\end{array}$ & $\begin{array}{c}\text { Internal argon } \\
\text { gas flow } \\
\left(\mathrm{mL} \mathrm{min}^{-1}\right)\end{array}$ \\
\hline 1 & 70 & 1 & 22 & 300 \\
2 & 130 & 1 & 10 & 300 \\
3 & 400 & 1 & 20 & 300 \\
4 & 1500 & 0 & 5 & 100 \\
5 & 2000 & 1 & 4 & 300 \\
\hline
\end{tabular}


Cadmium in ammonium oxalate and acid digested extracts which was below the detection limit of flame AAS was complexed with $40 \%$ potassium iodide (KI) and then extracted into MIBK (Aziz-AlRahman et al. 1983). The Cd in the MIBK extract was determined using furnace AAS as described above.

\section{Soil Analysis}

All laboratory ware used was cleaned in $0.1 \mathrm{M} \mathrm{Na} 2$ EDTA and $1 \mathrm{M} \mathrm{HCl}$. Solutions of $\mathrm{KCl}$, $\mathrm{BaCl}_{2}$ and $\mathrm{Ca}\left(\mathrm{NO}_{3}\right)_{2}$ were prepared from stock solutions which had been earlier purified with dithiozone extracted in chloroform to remove any trace amounts of $\mathrm{Cd}$ (Hewitt 1952). All other solutions were prepared from AR grade reagents.

Total $\mathrm{Cd}$ in each soil was estimated by digestion with $\mathrm{HNO}_{3} / \mathrm{HClO}_{4} / \mathrm{HF} / 6 \mathrm{M} \mathrm{HCl}$ concentrated acids (Elliott and Shields 1988). Soils 1-3 were also extracted by a mixture of $0.005 \mathrm{M}$ EDTA and $0.01 \mathrm{M} \mathrm{Ca}\left(\mathrm{NO}_{3}\right)_{2}$ (Fujii and Corey 1986). Organic carbon was determined by the method of Yeomans and Bremner (1988). The $\mathrm{pH}$ was measured in soil solutions extracted by the method of Gillman and Bell (1978). Iron and aluminium (Al) extracted by ammonium oxalate were determined by flame AAS (Searle and Daly 1977). Iron and Al in residual (Table 2) and total digests $\left(\mathrm{HNO}_{3} / \mathrm{HClO}_{4} / \mathrm{HF} / 6 \mathrm{M} \mathrm{HCI}\right.$ concentrated acids) were also analysed by flame AAS.

\section{Results}

In all the soils, $\mathrm{pH}$ had a marked effect on the amount and percentage of $\mathrm{Cd}$ (\%Cd) in each form at all the rates of $\mathrm{Cd}$ application except when no $\mathrm{Cd}$ was applied. The \% Cd is the amount of $\mathrm{Cd}$ in each form expressed as a percentage of the sum of amounts of $\mathrm{Cd}$ extracted by each solution in the sequential scheme.

\section{Forms of Native Cd}

No Cd was extracted from soils 1 and 2 by any of the solutions in the sequential extraction scheme, except by the concentrated acid extraction, i.e. 0.07 and 0.14 $\mu \mathrm{g} \mathrm{g}^{-1}$ respectively (data not shown). No $\mathrm{Cd}$ was extractable from soils 3 and 4 in any form.

\section{Forms of Added $C d$}

The amount of $\mathrm{Cd}$ in the $\mathrm{KCl}$ extracts decreased exponentially in all the soils with increasing soil solution $\mathrm{pH}$, except soil 3 where it increased linearly with $\mathrm{pH}$ (Fig. 1). The rate of decrease for soils 1,2 and 4 between $\mathrm{pH} 4$ and 6 was greater at higher additions of $\mathrm{Cd}$ and was in the order of the soils $1>2>4$ (Figs $1 a, 1 b$ and $1 d$ ). In soil 3 , the rate of increase was greater at the higher rates of $\mathrm{Cd}$ application (Fig. 1c).

The variation in the $\mathrm{BaCl}_{2}$-extractable $\mathrm{Cd}$ with $\mathrm{pH}$ depended upon the soil type (Fig. 2). At a constant rate of $\mathrm{Cd}$ addition and $\mathrm{pH}$, the amount of $\mathrm{Cd}$ in this form was in the order of soil $2>$ soil $3>$ soil $4>$ soil 1 up to $\mathrm{pH} 5$ and at $\mathrm{pH} 7$ the order changed to soil $4>$ soil $2>$ soil $3>$ soil 1 . There was approximately twice as much $\mathrm{Cd}$ in this form in soil 2 than in soil 1 . For both soils, $\mathrm{Cd}-\mathrm{BaCl}_{2}$ increased with $\mathrm{pH}$ up to 5 and then decreased. The curvature of the line increased with application rate of Cd (Figs $2 a$ and $2 b$ ). In soil 3 , $\mathrm{Cd}-\mathrm{BaCl}_{2}$ decreased linearly with $\mathrm{pH}$ at all the rates of Cd application (Fig. $2 c$ ). In soil $4, \mathrm{Cd}-\mathrm{BaCl}_{2}$ increased asymptotically except when $0.8 \mu \mathrm{g} \mathrm{g}^{-1} \mathrm{Cd}$ was added (Fig. 2d).

Cadmium extracted by $\mathrm{NaOCl}$ from soils 1,2 and 4 represented only a small fraction of the total $\mathrm{Cd}$ at all $\mathrm{pH}$ values, whereas in soil 3 this fraction represented 

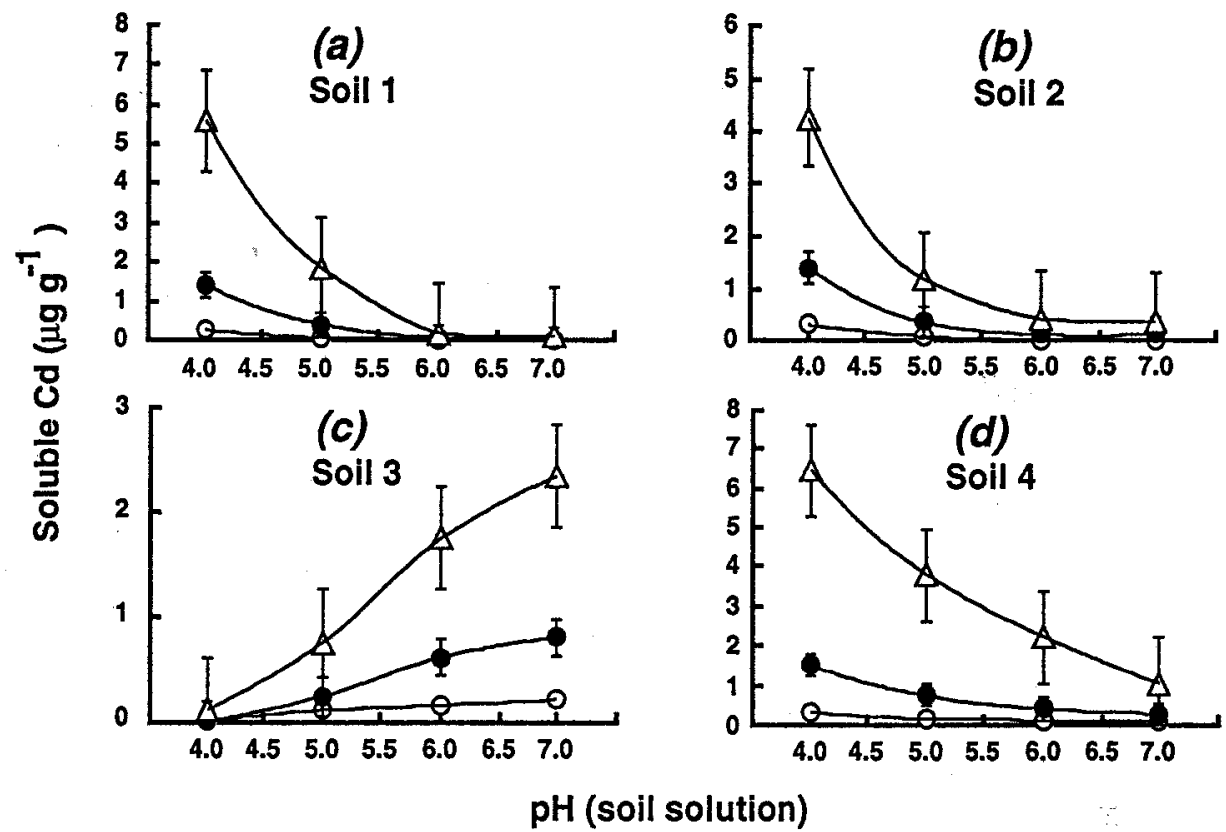

Fig. 1. The relationship between soil solution $\mathrm{pH}$ and soluble $\mathrm{Cd}$ at application rates of $0.8(O), 3.2(\bullet)$ and $10 \mu \mathrm{g} \mathrm{Cd} \mathrm{g}^{-1}(\Delta)$ in $(a)$ soil $1,(b)$ soil $2,(c)$ soil 3 and (d) soil 4 . The vertical bar denotes the standard error.

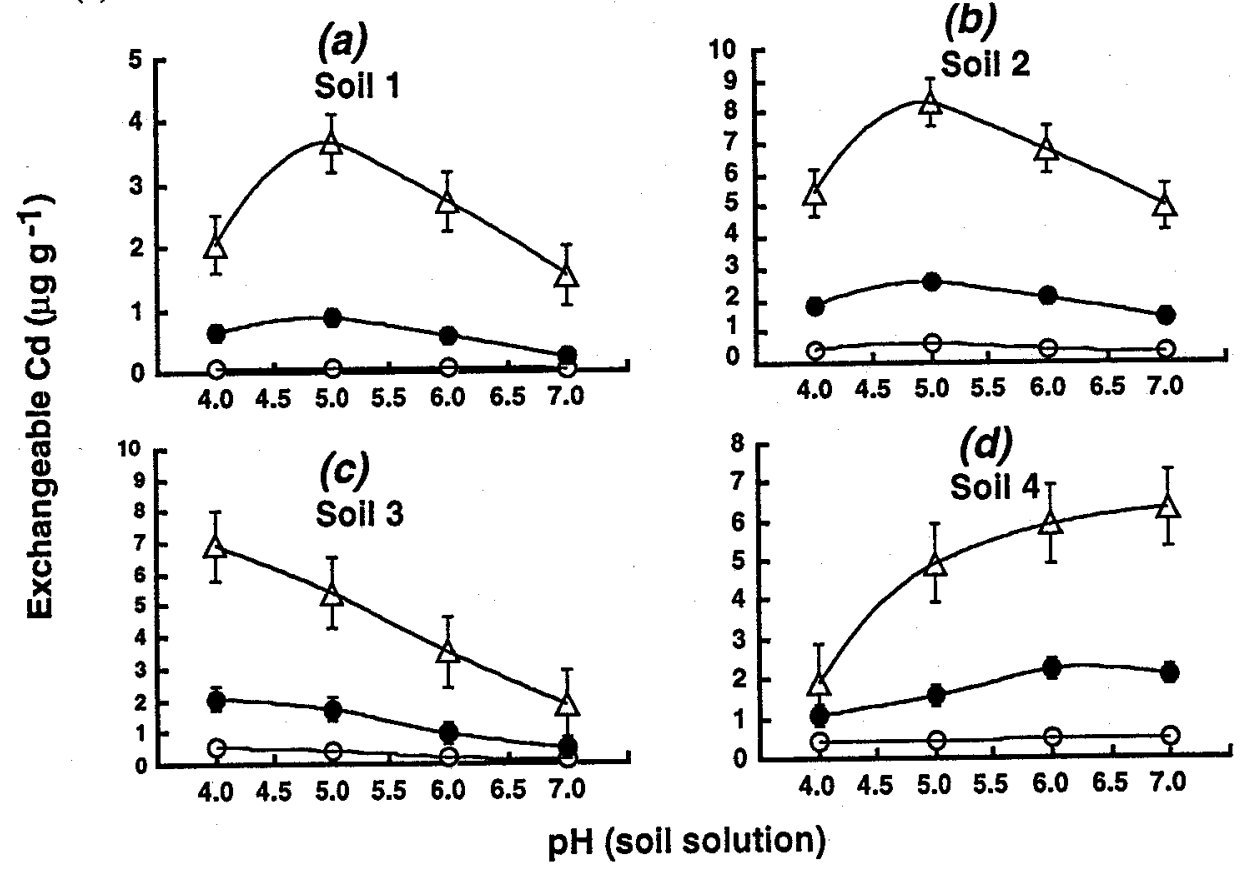

Fig. 2. The relationship between soil solution $\mathrm{pH}$ and exchangeable $\mathrm{Cd}$ at application rates of $0.8(\bigcirc), 3.2(\bullet)$ and $10 \mu \mathrm{g} \mathrm{Cd} \mathrm{g}^{-1}(\Delta)$ in $(a)$ soil $1,(b)$ soil $2,(c)$ soil 3 and (d) soil 4 . The vertical bar denotes the standard error. 


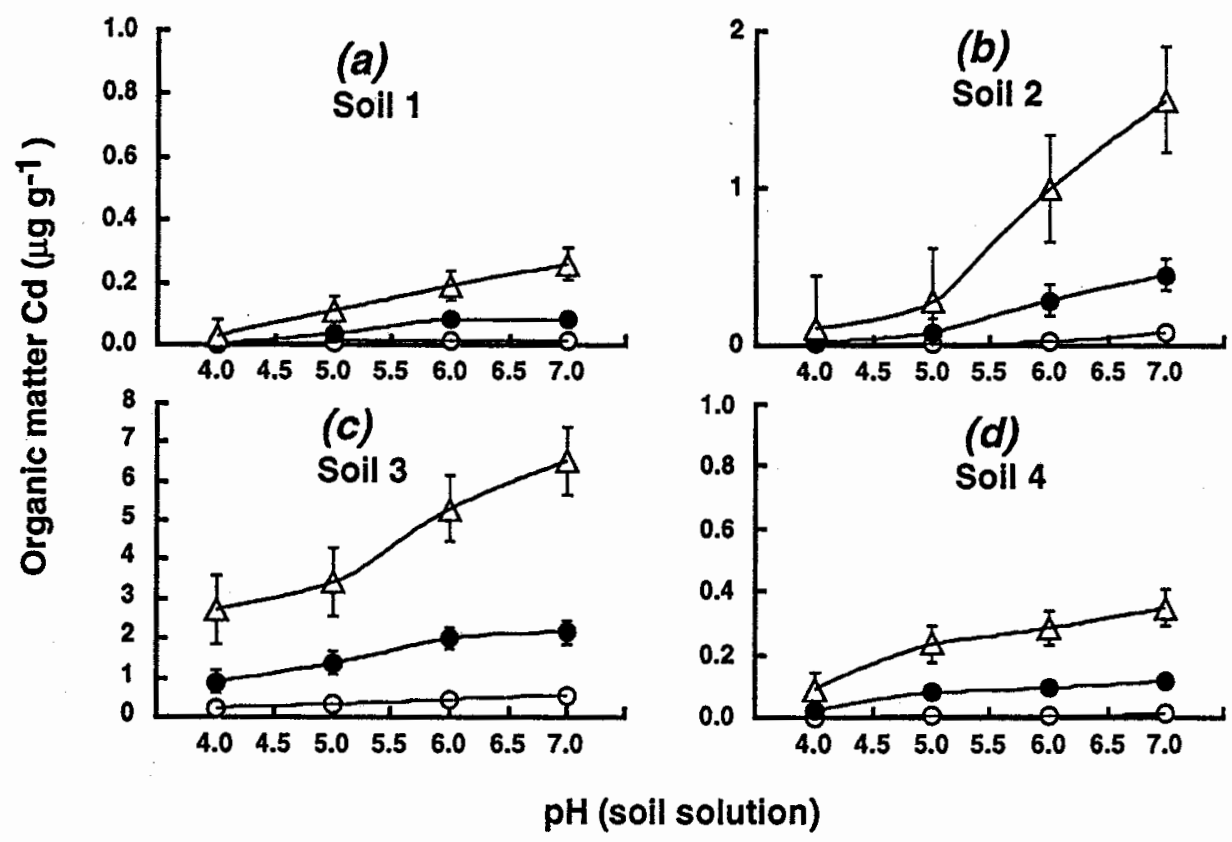

Fig. 3. The relationship between soil solution $\mathrm{pH}$ and $\mathrm{Cd}$ bound to organic matter at application rates of $0 \cdot 8(\mathrm{O}), 3 \cdot 2,(\bullet)$ and $10 \mu \mathrm{g} \mathrm{Cd}^{-1}(\Delta)$ in $(a)$ soil $1,(b)$ soil $2,(c)$ soil 3 , and $(d)$ soil 4 . The vertical bar denotes the standard error.

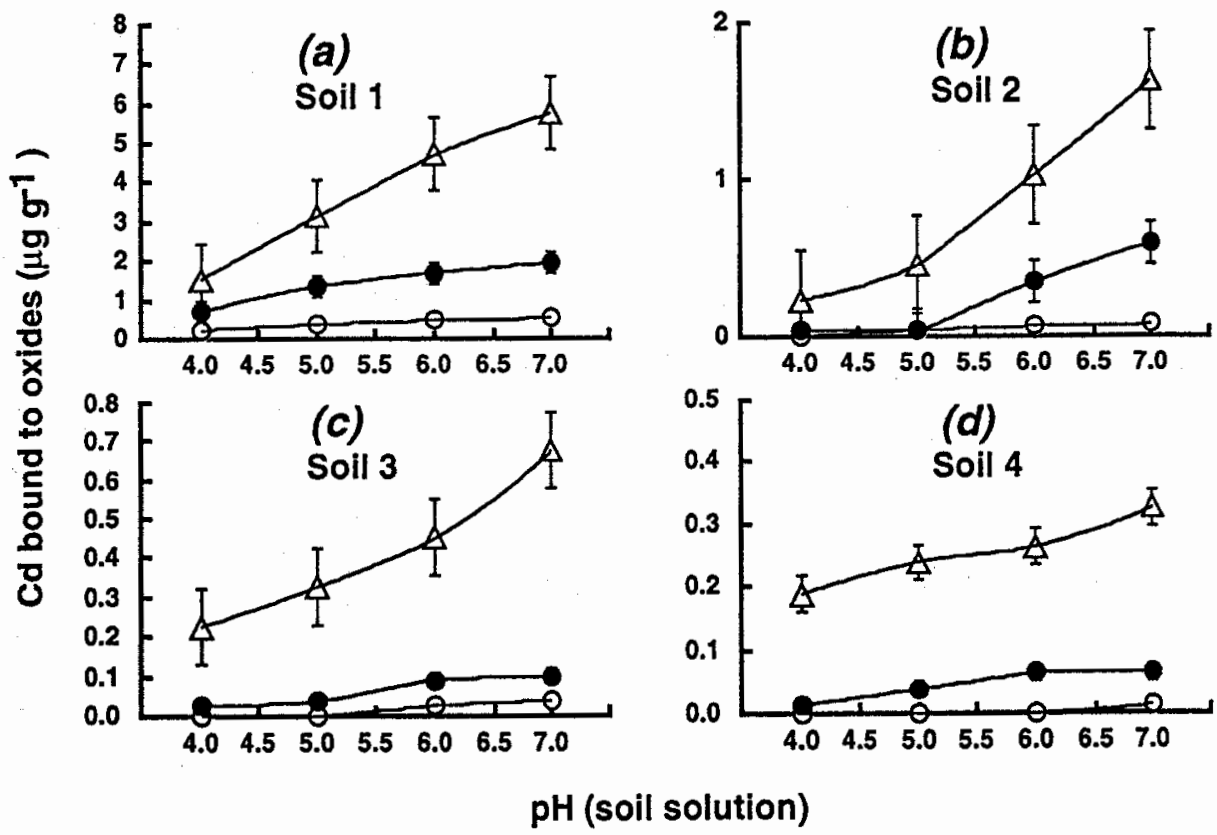

Fig. 4. The relationship between soil solution $\mathrm{pH}$ and $\mathrm{Cd}$ bound to oxides/clays at application rates of $0.8(\bigcirc), 3 \cdot 2,(\bullet)$ and $10 \mu \mathrm{g} \mathrm{Cd} \mathrm{g}^{-1}(\triangle)$ in $(a)$ soil $1,(b)$ soil $2,(c)$ soil 3 and $(d)$ soil 4 . The vertical bar denotes the standard error. 

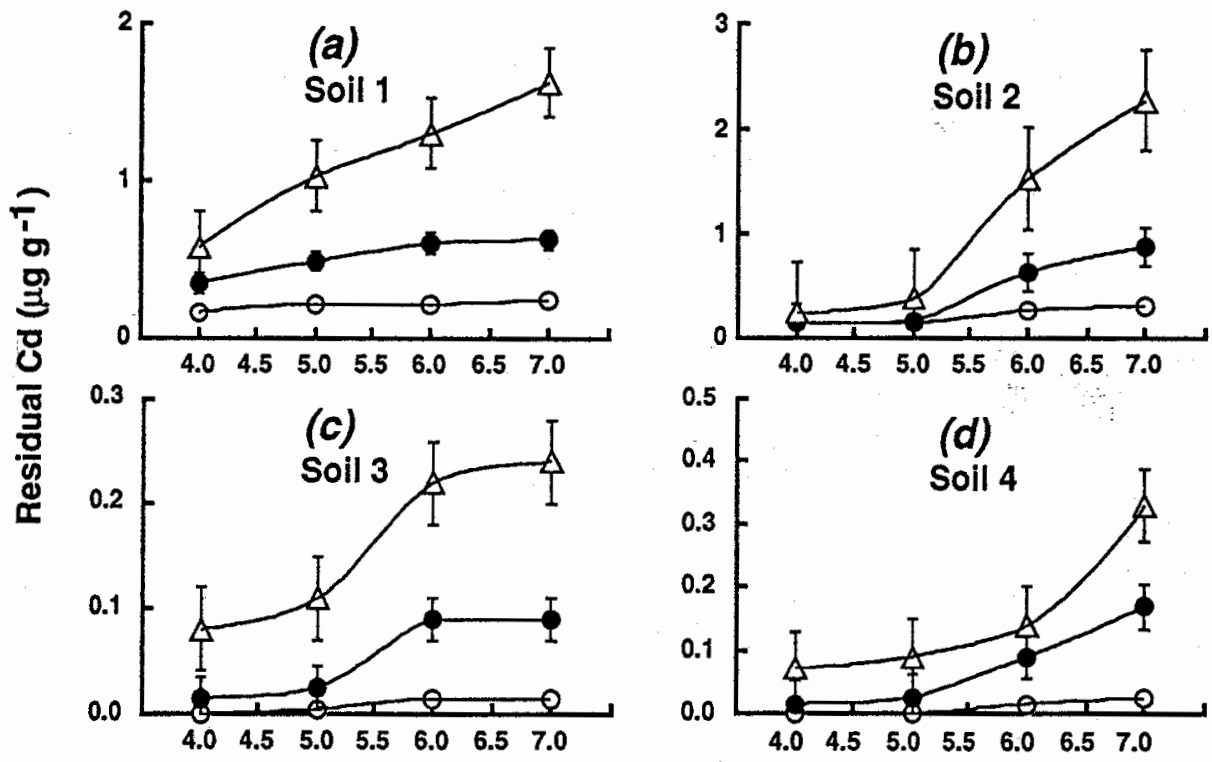

\section{$\mathrm{pH}$ (soil solution)}

Fig. 5. The relationship between soil solution $\mathrm{pH}$ and residual $\mathrm{Cd}$ at application rates of $0 \cdot 8(0), 3 \cdot 2,(\bullet)$ and $10 \mu \mathrm{g} \mathrm{Cd} \mathrm{g}^{-1}(\triangle)$ in $(a)$ soil $1,(b)$ soil $2,(c)$ soil 3 and (d) soil 4. The vertical bar denotes the standard error.

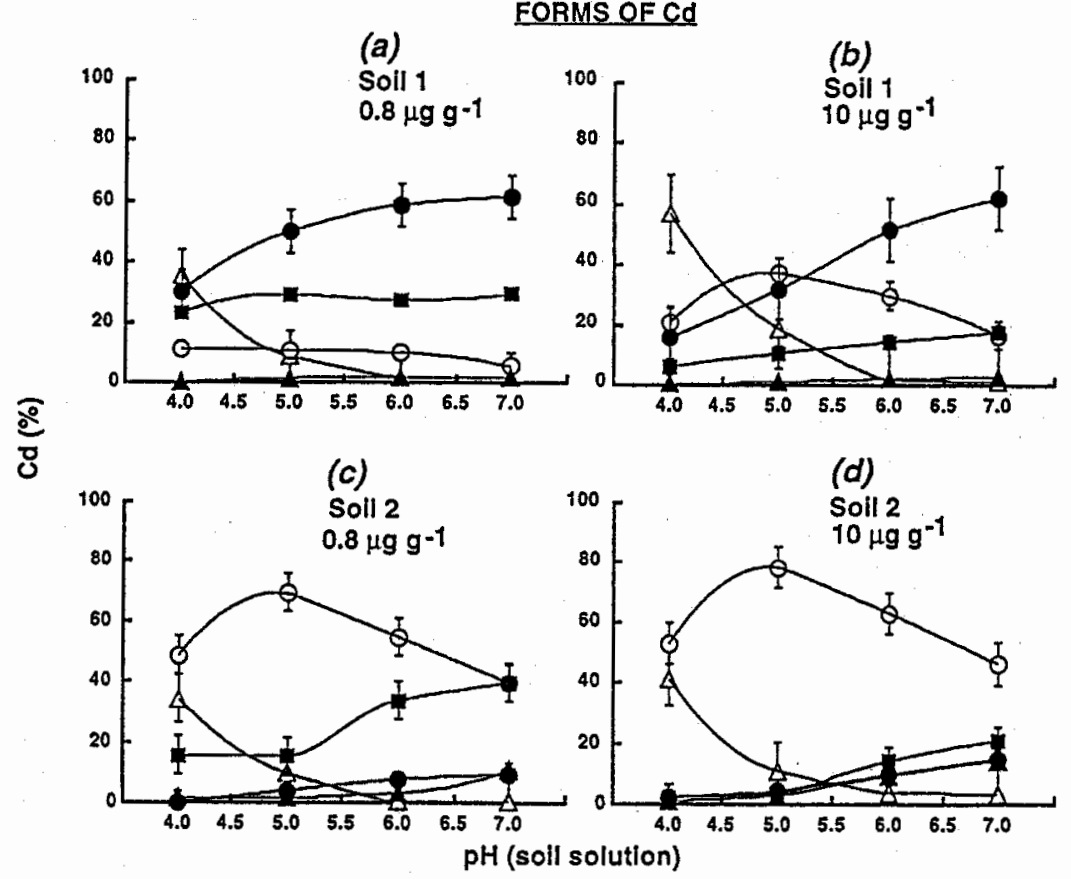

Fig. 6. Effect of soil solution $\mathrm{pH}$ in soil 1 at $\mathrm{Cd}$ application rates of $(a) 0.8 \mu \mathrm{g} \mathrm{g}^{-1}$ and (b) $10 \mu \mathrm{g} \mathrm{g}^{-1}$, and in soil 2 at (c) $0.8 \mu \mathrm{g} \mathrm{g}^{-1}$ and $(d) 10 \mu \mathrm{g} \mathrm{g}^{-1}$ on \% soluble $\mathrm{Cd}(\triangle), \%$ exchangeable $\mathrm{Cd}(\mathrm{O}), \% \mathrm{Cd}$ bound to organic matter $(\Delta), \% \mathrm{Cd}$ bound to oxides/clays $(\mathbf{)}$ ) and \%Cd in the residual form( $(\square)$. 


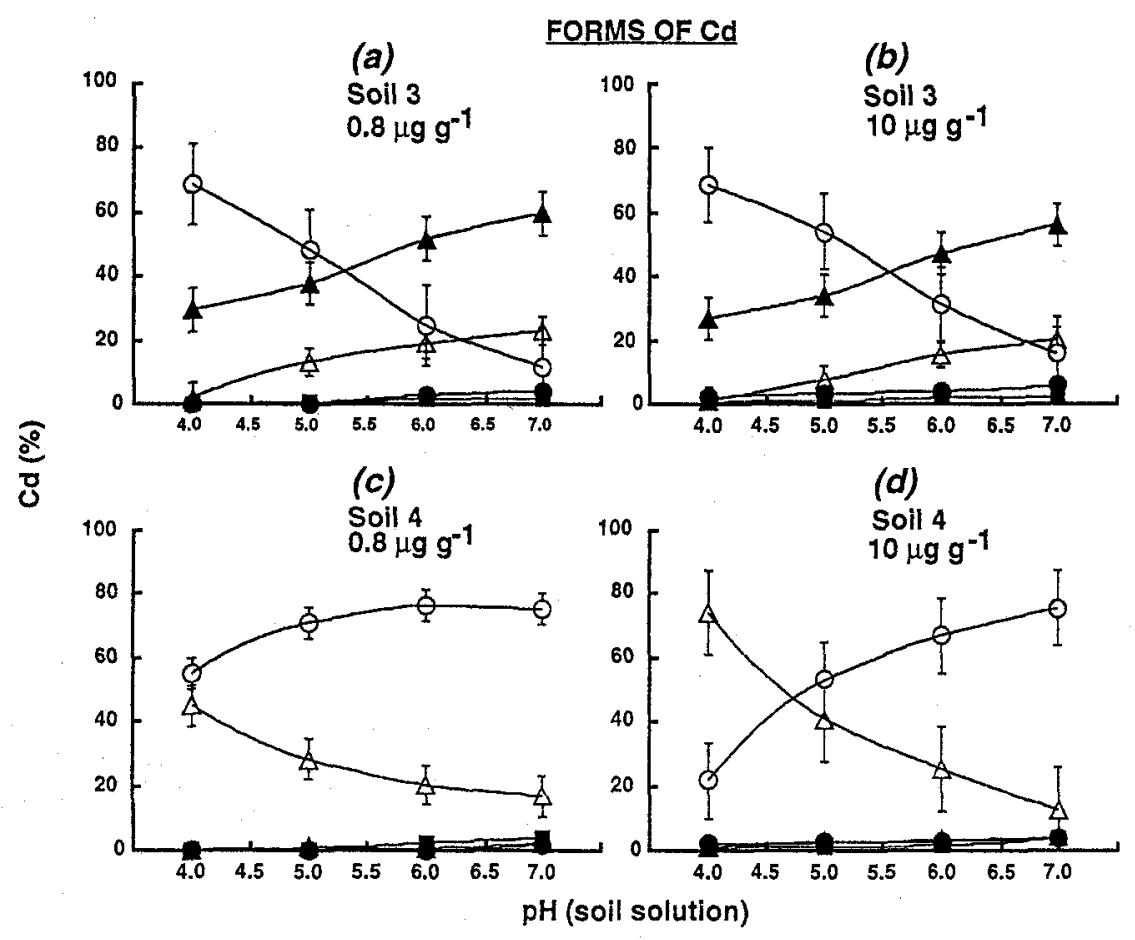

Fig. 7. Effect of soil solution $\mathrm{pH}$ in soil 3 at $\mathrm{Cd}$ application rates of $(a) 0.8 \mu \mathrm{g} \mathrm{g}^{-1}$ and $(b) 10 \mu \mathrm{g} \mathrm{g}^{-1}$, and in soil $4(c)$ at $0.8 \mu \mathrm{g} \mathrm{g}^{-1}$ and $(d) 10 \mu \mathrm{g} \mathrm{g}^{-1}$ on $\%$ soluble $\mathrm{Cd}(\triangle), \%$ exchangeable $\mathrm{Cd}(\mathrm{O}), \% \mathrm{Cd}$ bound to organic matter $(\boldsymbol{\Delta}), \% \mathrm{Cd}$ bound to oxides/clays (O) and $\% \mathrm{Cd}$ in the residual form $(\mathbf{D})$.

the majority of total $\mathrm{Cd}$ at all $\mathrm{pH}$ values, (Fig. 3). The amount of $\mathrm{Cd}-\mathrm{NaOCl}$ increased with increase in $\mathrm{pH}$ and with rate of $\mathrm{Cd}$ addition and was in the order soil $3 \gg$ soil $2 \gg$ soil $1 \approx$ soil 4 .

The amount of $\mathrm{Cd}$ extracted by ammonium oxalate $(\mathrm{AO})$ from each soil increased with increase in $\mathrm{pH}$ and with the rate of $\mathrm{Cd}$ application (Fig. 4). The rate of increase was in the order soil $1 \gg$ soil $2>$ soil $3>$ soil 4 . The slope of the increase in the amount of AO-extractable $\mathrm{Cd}$ with $\mathrm{pH}$ increased with increasing rate of $\mathrm{Cd}$ addition in all the soils.

The amounts of acid-extractable $\mathrm{Cd}$ increased with $\mathrm{pH}$ and with rate of $\mathrm{Cd}$ application in all four soils and were in the order soil $2>$ soil $1>$ soil $4>$ soil 3 (Fig. 5).

The \%Cd extracted by $\mathrm{KCl}(\% \mathrm{Cd}-\mathrm{KCl})$ in soils 1,2 and 4 decreased exponentially with $\mathrm{pH}$ and was similar for all the rates of $\mathrm{Cd}$ addition (Fig. 6 and 7). In soil 3 , the $\% \mathrm{Cd}-\mathrm{KCl}$ increased linearly with $\mathrm{pH}$ from $0-20 \%$ at all rates of $\mathrm{Cd}$ addition (Fig. $7 a$ and $7 b$ ). The $\% \mathrm{Cd}-\mathrm{KCl}$ at $\mathrm{pH} 4$ was highest $(75 \%)$ in soil 4 and lowest $(<2 \%)$ in soil 3 at all the rates of $\mathrm{Cd}$ application. The largest decrease (30-40\%) was observed between $\mathrm{pH} 4$ and 5 in soils 1,2 and 4 . The fraction decreased from approximately $50 \%$ to almost zero in soils 1 and 2 when the pH increased from 4 to 6 and no further change was observed between pH 6 and 7 . 
At the $10 \mu \mathrm{g} \mathrm{g}^{-1} \mathrm{Cd}$ rate in soil 4 , however, the fraction was $75 \%$ at $\mathrm{pH} 4$ and continuously decreased with increase in $\mathrm{pH}$ to $15 \%$ at $\mathrm{pH} 7$ (Figs $7 c$ and $7 d$ ).

The variation in $\% \mathrm{Cd}$ extracted by $\mathrm{BaCl}_{2}\left(\% \mathrm{Cd}-\mathrm{BaCl}_{2}\right)$ with $\mathrm{pH}$ for soils 1 , 2 and 4 was similar to the amounts of $\mathrm{Cd}-\mathrm{BaCl}_{2}$ except that $\% \mathrm{Cd}-\mathrm{BaCl}_{2}$ in soil 2 was more or less independent of the $\mathrm{Cd}$ application rate (Figs $6 c$ and $6 d$ ). In soil $3, \% \mathrm{Cd}-\mathrm{BaCl}_{2}$ decreased with increase in $\mathrm{pH}$ and was independent of the application rate (Figs $7 a$ and $7 b$ ).

In soils 1 and 4 , the variation in \%Cd extracted by $\mathrm{NaOCl}(\% \mathrm{Cd}-\mathrm{NaOCl})$ with $\mathrm{pH}$ and rate of $\mathrm{Cd}$ addition was inconsistent. The values were $<4 \%$ of the total $\mathrm{Cd}$ extracted by the sequential scheme and hence were considered to be negligible (data not shown). In soils 2 and 3 , the $\% \mathrm{Cd}-\mathrm{NaOCl}$ increased by approximately $12 \%$ and $30 \%$ respectively with increase in $\mathrm{pH}$ from 4 to 7 (Figs $6 c$ and $6 d$; Figs $7 a$ and $7 b$ ).

The \%Cd extracted by ammonium oxalate (\%Cd-AO) in all the soils increased with increase in $\mathrm{pH}$ and was in the order soil $1 \gg$ soil $2>$ soil $3>$ soil 4 (Figs 6 and 7 ). In soil 1 , at a constant $\mathrm{pH}$, the $\% \mathrm{Cd}-\mathrm{AO}$ tended to decrease as the rate of $\mathrm{Cd}$ application increased. The increase in \%Cd-AO in soil 2 with increase in $\mathrm{pH}$ from 4 to 7 was almost similar $(\approx 15 \%)$ at 3.2 and $10.0 \mu \mathrm{g} \mathrm{g}^{-1} \mathrm{Cd}$ rates, whereas at $0.8 \mu \mathrm{g} \mathrm{g}^{-1}$ this fraction increased by $<10 \%$. In soils 3 and 4 , the $\% \mathrm{Cd}-\mathrm{AO}$ was almost negligible $(<2 \%)$ at $\mathrm{pH} 4$ at all the rates of $\mathrm{Cd}$ application and, even with an increase in $\mathrm{pH}$ from 4 to 7 , the fraction increased by $<5 \%$ (Fig. 7).

The \% Cd extracted by acids (\% Cd-acid) increased with increase in $\mathrm{pH}$ in the four soils and the trend was more or less similar to the amounts of acid-extractable $\mathrm{Cd}$ (Figs 6 and 7). The highest amount of \%Cd-acid (40\%) was found in soil 2 at $\mathrm{pH} 7$ where $0.8 \mu \mathrm{g} \mathrm{g}^{-1}$ of $\mathrm{Cd}$ was applied (Fig. $6 c$ ). In soil $1, \% \mathrm{Cd}$-acid increased from $5-15 \%$ with increase in $\mathrm{pH}$ from 4 to 7 at the $10 \mu \mathrm{g} \mathrm{g}^{-1} \mathrm{Cd}$ application rate; however, at the lower rate $\left(0.8 \mu \mathrm{g} \mathrm{g}^{-1}\right)$ of $\mathrm{Cd}$ application, it remained almost constant $(\approx 22 \%)$ at all the $\mathrm{pH}$ values (Figs $6 a$ and $6 b)$. In soils 3 and $4, \% \mathrm{Cd}$-acid was a small fraction $(<6 \%)$ and increased slightly with increase in $\mathrm{pH}$; however, it varied inconsistently with rate of $\mathrm{Cd}$ addition (Figs $7 a-d$ ).

\section{Extraction of $\mathrm{Cd}$ with $\mathrm{EDTA} / \mathrm{Ca}\left(\mathrm{NO}_{3}\right)_{2}$ and its Relationship with the Forms of $C d$}

Cadmium extracted by EDTA from soils 1,2 and 3 did not correlate well with any of the individual amounts of $\mathrm{Cd}$ extracted by $\mathrm{KCl}, \mathrm{BaCl}_{2}, \mathrm{NaOCl}, \mathrm{AO}$ and the acid digests at any of the $\mathrm{pH}$ values and at any of the rates when extracted sequentially. However, Cd-EDTA correlated well with total Cd (extraction by $\mathrm{HNO}_{3} / \mathrm{HClO}_{4} / \mathrm{HF} / 6 \mathrm{M} \mathrm{HCl}$ concentrated acids) and the sum of $\mathrm{Cd}$ extracted by $\mathrm{KCl}, \mathrm{BaCl}_{2}$ and ammonium oxalate $\left(r^{2}>0 \cdot 90\right)$. The sum of the $\mathrm{Cd}$ extracted by the above three extractants also correlated well with the total $\mathrm{Cd}$ in the four soils $\left(r^{2}>0.98\right)$.

\section{Discussion}

The forms of added $\mathrm{Cd}$ after incubation with each soil depended on $\mathrm{pH}$, mineralogy, organic matter and the application rate of $\mathrm{Cd}$. 
The major adsorption surface differed between soils and varied with $\mathrm{pH}$ for a particular soil. The extent of retention depended on the amount of adsorbing surface and $\mathrm{pH}$. In the siliceous sand, $\mathrm{Cd}$ was mainly present as the soluble $(\mathrm{KCl})$ and the exchangeable $\left(\mathrm{BaCl}_{2}\right)$ forms because of the lack of soil components with adsorption sites. In the peaty sand, organic matter was the main adsorbing surface present and hence the majority of $\mathrm{Cd}$ was extracted by $\mathrm{NaOCl}$ and $\mathrm{BaCl}_{2}$. Cadmium extracted by $\mathrm{NaOCl}$ would have removed $\mathrm{Cd}$ from organic adsorption sites, whereas $\mathrm{BaCl}_{2}$ may have extracted exchangeable $\mathrm{Cd}$ from both organic and inorganic exchange sites. In the yellow earth, $\mathrm{Cd}$ bound to oxides or specifically adsorbed $\mathrm{Cd}$ was the dominant form, whereas exchangeable $\mathrm{Cd}$ was more prevalent in the lateritic podzolic.

Increasing $\mathrm{pH}$ tended to increase the number of exchange and specifically adsorbed sites as well as organic sites. However, the amount and \%Cd in these forms only increased with $\mathrm{pH}$ if it was the major form in a particular soil or there were sufficient sites onto which $\mathrm{Cd}$ could adsorb.

The rate of application of $\mathrm{Cd}$ affected the amount of $\mathrm{Cd}$ in a particular form when the number of adsorption sites on the main adsorption component became limiting. The excess $\mathrm{Cd}$ not adsorbed by the main adsorption component was then retained by another form. For example, when exchangeable sites in the siliceous sand were saturated, $\% \mathrm{Cd}-\mathrm{KCl}$ increased because it was the only other significant form of $\mathrm{Cd}$ in that soil. In contrast, when the sites on oxide surfaces became limiting in the yellow earth, the excess $\mathrm{Cd}$ was adsorbed at exchange sites.

In the siliceous sand, most of the $\mathrm{Cd}(>95 \%)$ is present in the soluble $(\% \mathrm{Cd}-\mathrm{KCl})$ and the exchangeable form $\left(\% \mathrm{Cd}-\mathrm{BaCl}_{2}\right)$ and the proportion in both forms varied with $\mathrm{pH}$ and amount of $\mathrm{Cd}$ applied (Figs $7 c$ and $7 d$ ). At $\mathrm{pH} \mathrm{4,}$ the \%Cd that was soluble increased with the amount of $\mathrm{Cd}$ applied, presumably because there were no more exchange sites available for adsorption of additional Cd. As $\mathrm{pH}$ increased, a greater proportion of $\mathrm{Cd}$ was in the exchangeable form due to a concurrent increase in the number of exchange sites with $\mathrm{pH}$. The increase was not as great as that observed by Christensen (1984) who found that $\mathrm{Cd}$ adsorption increased by a factor of 3 per $\mathrm{pH}$ unit in sandy soils when $\mathrm{pH}$ increased from 4 to $7 \cdot 7$. Williams and David (1973) found that $>50 \%$ of the total Cd in seven yellow podzolic soils (Dy 3.42) was in the exchangeable form but they did not report $\mathrm{pH}$ values. The $\% \mathrm{Cd}$ in the exchangeable fraction at higher $\mathrm{pH}$ did not decrease with increase in rate of $\mathrm{Cd}$ application because there were more sites available for exchange (Figs $7 c$ and $7 d$ ). Cadmium bound to organic matter (\% Cd-NaOCl), Fe/Al oxides (\% Cd-AO) and that in the residual form (\%Cd-acid) was $<4 \%$ at all the $\mathrm{pH}$ values, as may be expected from soils low in organic matter, clay and hydrous oxide content (Table 1).

In the peaty sand, exchangeable $\mathrm{Cd}$ and that bound to organic matter were the major forms present. The relative importance depended upon $\mathrm{pH}$ and $\mathrm{Cd}$ application rate. As $\mathrm{pH}$ increased, more organic sites were formed at which $\mathrm{Cd}$ was preferentially adsorbed. The organic sites apparently had a higher affinity for $\mathrm{Cd}$ than the exchangeable sites. However, as the $\mathrm{Cd}$ application rate increased, the number of organic sites per mole of $\mathrm{Cd}$ decreased to the extent that some $\mathrm{Cd}$ remained in the exchangeable form due to a lack of high affinity organic sites. Hence, the $\mathrm{pH}$ at which there was an equal percentage of $\mathrm{Cd}$ present as organic 
and exchangeable forms rose as the application rate of $\mathrm{Cd}$ increased (Figs $7 a$ and $7 b$ ). Increases in $\mathrm{Cd}$ bound to organic matter as soil $\mathrm{pH}$ is increased have been observed previously (Levi-Minzi et al. 1976; McBride et al. 1981; Gerritse et al. 1982).

In the peaty sand at $\mathrm{pH}<5$, the presence of organic matter lowered the amount of $\mathrm{Cd}-\mathrm{KCl}$ in comparison with that in the siliceous sand. Decreases in Cd mobility under acidic conditions have been shown in the presence of organic matter (Tyler and McBride 1982). Tiller (1988) also suggested that organic matter-rich surfaces had a high $\mathrm{Cd}$ affinity at $\mathrm{pH}$ values $<6$. At $\mathrm{pH}>5$, however, an increase in the soluble form of $\mathrm{Cd}$ with increase in $\mathrm{pH}$ was observed. An increasingly brown coloration of the $\mathrm{KCl}$ extract as the $\mathrm{pH}$ rose suggested that the dissolution of organic material complexed with $\mathrm{Cd}$ could have been occurring. This phenomenon has been observed for $\mathrm{Cd}$ in acid soils amended with sodium hydroxide (Kuo and Baker 1980). Cadmium bound to $\mathrm{Fe} / \mathrm{Al}$ oxides or that in the residual fraction was $<4 \%$ of total $\mathrm{Cd}$ at all $\mathrm{pH}$ values and at all the rates of $\mathrm{Cd}$ application, as would be expected for soils low in hydrous oxides and clay with a sandy texture (Table 1).

In the yellow earth soil, Cd bound to hydrous oxides was the major form except when the $\mathrm{pH}$ was low $(\leq 6)$ and the application rate was high $(10 \mu \mathrm{g}$ $\mathrm{g}^{-1}$, Fig. $6 b$ ). In the latter situation, the presence of a small number of sites available for $\mathrm{Cd}$ adsorption onto hydrous oxides would have limited the $\% \mathrm{Cd}$ that could be adsorbed. At $\mathrm{pH} 4$, most of the excess Cd stayed in the soluble form whereas at $\mathrm{pH} 5$ the majority was adsorbed at exchange sites, presumably because of the development of $\mathrm{pH}$-dependent negative sites. As $\mathrm{pH}$ increased, an appreciable increase in $\mathrm{Cd}$ bound to hydrous oxides occurred even at the higher rates of $\mathrm{Cd}$ application, suggesting a further increase in the number of negative sites for specific adsorption. On the other hand, exchangeable $\mathrm{Cd}$ reached a maximum at $\mathrm{pH} 5$ and, with further increase in $\mathrm{pH}$, this fraction started to decline, possibly because the higher strength of $\mathrm{Cd}$ bonding with oxides favoured specific adsorption of $\mathrm{Cd}$ at the expense of exchangeable $\mathrm{Cd}$ held by less strength, i.e. coulombic attraction (Tiller 1988). Goethite and kaolinite are the major adsorbing surfaces in this soil (Table 1). The general predominance of specifically adsorbed $(\mathrm{Cd}-\mathrm{AO})$ over exchangeable $\left(\mathrm{Cd}-\mathrm{BaCl}_{2}\right)$ suggests that the $\mathrm{Fe}$ oxide may have been present predominantly as a coating on the kaolinite. Increases in $\mathrm{Cd}$ adsorption with increase in $\mathrm{pH}$ have been observed by several researchers for soils (Garcia-Miragaya and Page 1977; Jarvis and Jones 1980), clays (Farrah and Pickering 1977), and for goethite (Tiller et al. 1984). The increase in residual $\mathrm{Cd}$ with application rates at all $\mathrm{pH}$ values suggests the occlusion of $\mathrm{Cd}$ or its diffusion into less accessible sites from which $\mathrm{Cd}$ is not displaced by $\mathrm{AO}$ or $\mathrm{BaCl}_{2}$.

Exchangeable $\mathrm{Cd}$ was the major form of $\mathrm{Cd}$ in the lateritic podzolic soil, as may be expected for a soil with kaolinite as the major clay and negligible amounts of hydrous oxides (Table 1). The proportion in the exchangeable form depended mainly on $\mathrm{pH}$, whereas the application rate of $\mathrm{Cd}$ had a minimal effect, presumably because there was an excess of exchange sites. At each application rate, exchangeable $\mathrm{Cd}$ reached a maximum at $\mathrm{pH} 5$ and then declined with further increase in $\mathrm{pH}$. The decrease in exchangeable $\mathrm{Cd}$ at $\mathrm{pH}>5$ could not be explained by a limited number of exchange sites because the $\% \mathrm{Cd}$ in this form was independent of application rate. The observed decrease in exchangeable $\mathrm{Cd}$ 
at higher $\mathrm{pH}$ values coincided with an increase in residual $\mathrm{Cd}$, possibly indicating that, at higher $\mathrm{pH}$ values, some exchange sites are less accessible than others and the $\mathrm{Cd}$ adsorbed at such sites is only displaced by an acid extraction. In addition, there was a small but concurrent increase in specifically bound $\mathrm{Cd}$ (\% Cd-AO) which could indicate the formation of some variable charge negative sites on the edges of kaolinite crystals at high $\mathrm{pH}$ values. Organically bound $\mathrm{Cd}$ also increased at high $\mathrm{pH}$ values, which may have been due to, not only an increase in negative sites, but also an increase in bonding energy.

In the sequential extraction of native $\mathrm{Cd}$ from the yellow earth and lateritic podzolic soils, most of the $\mathrm{Cd}$ (irrespective of $\mathrm{pH}$ ) was extracted by acid digestion $\left(0.07\right.$ and $0.14 \mu \mathrm{g} \mathrm{g}^{-1}$, respectively). This suggests that strong binding of $\mathrm{Cd}$ to oxides and clays or the occlusion/entrapment of $\mathrm{Cd}$ into the layer lattices of oxides and or kaolinite had occurred. Hence, in both soils, the possibility of Cd uptake by plants was decreased. This finding was in complete contrast to the sequential extraction of added $\mathrm{Cd}$. A possible explanation could be that, with time, Cd diffused into the mineral layer lattices of the oxides and or the clays (Brummer et al. 1988). Alternatively, the native $\mathrm{Cd}$ was originally present in the lattice during formation of the mineral.

\section{Implications for Cd Accumulation in Readily Leachable or Available Forms}

Soluble and exchangeable forms of $\mathrm{Cd}$ are considered to be the most labile and available pools for leaching and uptake by plants (Harrison et al. 1981; Soon and Bates 1982; Hickey and Kittrick 1984). Hence, the amount of Cd in these forms will be indicative of the potential for $\mathrm{Cd}$ accumulation in plants or for $\mathrm{Cd}$ contamination of ground waters via leaching. At $\mathrm{pH} 4$, the risk of $\mathrm{Cd}$ pollution from these soils is in the order siliceous sand $>$ lateritic podzolic $>$ yellow earth $>$ peaty sand at all rates of $\mathrm{Cd}$ application (Figs 6 and 7). However, at $\mathrm{pH} \mathrm{7,} \mathrm{the} \mathrm{risk} \mathrm{of} \mathrm{Cd}$ pollution from these soils was similar, with the exception that risk from the peaty sand was greater than that from the yellow earth. The results suggest that, at lower $\mathrm{pH}$ values, soils with appreciable organic matter would retain more $\mathrm{Cd}$ in forms that are unavailable or unleachable in comparison to soils with low organic matter. However, at higher $\mathrm{pH}$ values, soils with oxides would contribute more to $\mathrm{Cd}$ retention.

In many cases, fertilizers containing $\mathrm{Cd}$ as a contaminant are applied to the surface layers of a soil which usually have the highest organic matter content. Hence, it would be expected that the organic matter would adsorb $\mathrm{Cd}$ until all the sites were saturated. Any excess Cd would be in the exchangeable or soluble form and thereby be prone to leaching or uptake by plants. In situations where Cd leaches down the soil profile, it may intercept hydrous oxides or clays in subsurface layers and hence could become adsorbed. The amount of $\mathrm{Cd}$ adsorbed and that left in more soluble forms will again depend upon the $\mathrm{pH}$ of the soil, and the rate at which $\mathrm{Cd}$ was applied. However, when we compare the yellow earth and lateritic podzolic soils which contained the same amount of organic matter (Table 1), no Cd was adsorbed onto the organic matter in the yellow earth at any $\mathrm{pH}$ value, whereas in the lateritic podzolic, $15-20 \%$ of the $\mathrm{Cd}$ was adsorbed onto the organic matter at $\mathrm{pH}$ 7. This suggests that, when the number of sites on oxides are appreciable, $\mathrm{Cd}$ could be preferentially adsorbed by hydrous oxides at the expense of adsorption onto organic matter. In the lateritic podzolic 
soil, however, the sites on kaolinite apparently could not compete so effectively with organic matter for $\mathrm{Cd}$ (even when present in excess). Alternatively, the kaolinite was partially coated with organic matter so fewer inorganic adsorption sites were available for $\mathrm{Cd}$ adsorption.

Uptake of $\mathrm{Cd}$ by plants has been shown to increase with a decrease in $\mathrm{pH}$ (Williams and David 1977; Whitten and Ritchie 1991). Considering the original soil $\mathrm{pH}$ (soil solution) of the siliceous sand $(6 \cdot 0)$, peaty sand $(4 \cdot 0)$, lateritic podzolic soil $(3 \cdot 7)$ and yellow earth (5.4), nearly $90,70,80$ and $25 \%$ of the total $\mathrm{Cd}$ applied would be in the soluble and exchangeable forms and be of concern in terms of causing accumulation of $\mathrm{Cd}$ in the food chain or contaminating underground water. The estimates decrease to approximately 55, 0, 35 and $10 \%$ (respectively) if we assume that only soluble $\mathrm{Cd}$ is available to plants. However, the actual concentration of $\mathrm{Cd}$ in the soil solution alone cannot account for the amounts taken up by plants. Continuous depletion of $\mathrm{Cd}$ from the soil solution will result in its replenishment from solid phase sources in order to maintain equilibrium and would result in higher concentrations of $\mathrm{Cd}$ in plants than those that could be attributable to uptake from the soil solution alone (Hardiman et al. 1984). The replenishment of $\mathrm{Cd}$ in the soil solution of the yellow earth and lateritic podzolic soils may be limited to a certain extent by strong surface reactions, but in the peaty sand, organically bound $\mathrm{Cd}$ probably replenishes $\mathrm{Cd}$ in the soil solution more quickly (Gibson and Farmer 1986).

The amount of added Cd extracted by EDTA, when compared with total $\mathrm{Cd}$ and the forms of $\mathrm{Cd}$ extracted by the sequential extraction scheme from all of these soils, indicated that EDTA not only extracts Cd from the soluble and the exchangeable forms but also extracts $\mathrm{Cd}$ from the strongly adsorbed pool. Therefore, EDTA (which is commonly used in soil testing procedures for extracting micronutrients that are available to plants) may be more indicative of the total $\mathrm{Cd}$ in soils rather than of the available or the mobile forms of $\mathrm{Cd}$. EDTA has a strong chelating ability and has been used to solubilize poorly crystalline Fe oxides and their associated trace metals (Borggaard 1979).

Sequential extraction has limitations because solutions used for extracting particular forms of $\mathrm{Cd}$ may also partially extract $\mathrm{Cd}$ from some other pool. The sequential scheme used in this work appears to have been reasonably selective and has provided a guide to the potential for $\mathrm{Cd}$ to be in a form readily taken up by plants or to be lost by leaching.

\section{Conclusions}

A decrease in $\mathrm{pH}$ or the amount of adsorption components in the soil favoured $\mathrm{Cd}$ occurring in forms that were more soluble or absorbable by plants. However, the effect of $\mathrm{pH}$ on the forms of $\mathrm{Cd}$ differed among the soils studied because the nature of the adsorbing component (oxides, clays and organic matter) changed.

The forms of $\mathrm{Cd}$ were also influenced by the rate of $\mathrm{Cd}$ application. At lower rates, $\mathrm{Cd}$ was present as less soluble forms in soils dominated by oxides and the clays, whereas in siliceous and peaty sands, the $\mathrm{Cd}$ rate had no significant effect on the forms of $\mathrm{Cd}$. Thus, $\mathrm{Cd}$ would be more available to plants when it was applied at higher rates to soils dominated by oxides or clays and equally available in sandy soils and soils with organic matter at all the application rates. However, these generalizations can only be made for the application rates used in this study. 
This work has shown that the form of added Cd in a soil cannot be elucidated from considering the major adsorbing component alone. It is also necessary to know the $\mathrm{pH}$, the presence of other adsorbing surfaces and the rates of applied Cd.

\section{References}

Aziz-AlRahman, A. M., Al-Hajjaji, M. A., and Al-Zami, I. Z. (1983). Determination of lead and $\mathrm{Cd}$ in soils by atomic absorption spectrophotometry after solvent extraction as iodide complexes. Int. J. Environ. Anal. Chem. 15, 9-18.

Borggaard, O. K. (1979). Selective extraction of amorphous iron oxides by EDTA from a Danish sandy loam. J. Soil Sci. 30, 727-34.

Brown, G. (1954). Soil morphology and mineralogy. A qualitative study of some gleyed soils from North West England. J. Soil Sci. 5, 145-55.

Brummer, G., Gerth, J., and Tiller, K. G. (1988). Reaction kinetics of the adsorption and desorption of $\mathrm{Ni}, \mathrm{Zn}$ and $\mathrm{Cd}$ by goethite. 1. Adsorption and diffusion of metals. J. Soil Sci. 39, 37-51.

Christensen, T. H. (1984). Cadmium soil sorption at low concentrations: II. Reversibility effect of changes in solute composition, and effect of soil aging. Water, Air, Soil Pollut. 21, 105-14.

Dudas, M. J. (1974). The quantitative determination of Cd in soils by solvent extraction and flameless atomic absorption spectroscopy. Atom. Absorption Newsl. 13, 109-12.

Elliott, H. A., and Shields, G. A. (1988). Comparative evaluation of residual and total metal analyses in polluted soils. Commun. Soil Sci. Plant Anal. 19, 1907-15.

Farrah, H., and Pickering, W. F. (1977). Influence of clay-solute interactions on aqueous heavy metal ion levels. Water, Air, Soil Pollut. 8, 189-97.

Forbes, E. A., Posner, A. M., and Quirk, J. P. (1976). The specific adsorption of divalent Cd, $\mathrm{Co}, \mathrm{Cu}, \mathrm{Pb}$ and $\mathrm{Zn}$ on goethite. J. Soil Sci. 27, 154-66.

Fujii, R., and Corey, R. B. (1986). Estimation of isotopically exchangeable Cd and $\mathrm{Zn}$ in soils. Soil Sci. Soc. Am. J. 50, 306-8.

Garcia-Miragaya, J., and Page, A. L. (1977). Influence of exchangeable cation on the sorption of trace amounts of cadmium by montmorillonite. Soil Sci. Soc. Am. J. 41, 718-21.

Gerritse, R. G, Vriesma, R., Dalenberg, J. W., and DeRoos, H. P. (1982). Effect of sewage sludge on trace element mobility in soils. J. Environ. Qual. 11, 359-64.

Gibson, M. J., and Farmer, J. G. (1986). Multi-step sequential chemical extraction of heavy metals from urban soils. Environ. Pollut. (Ser. B) 11, 117-35.

Gillman, G. P., and Bell, L. C. (1978). Soil solution studies on weathered soils from tropical North Queensland. Aust. J. Soil Res. 16, 67-77.

Hardiman, R. T., Banin, A., and Jacoby, B. (1984). The effect of soil type and degree of metal contamination upon uptake of $\mathrm{Cd}, \mathrm{Pb}$ and $\mathrm{Cu}$ in bush beans (Phaseolus vulgaris L.). Plant Soil 81, 3-15.

Harrison, R. M., Laxe, D. P. H., and Wilson, S. J. (1981). Chemical associations of Pb, Cd, $\mathrm{Cu}$ and $\mathrm{Zn}$ in street dusts and roadside soils. Environ. Sci. Technol. 15, 1378-83.

Hewitt, E. J. (1952). Sand and water culture methods used in the study of plant nutrition. Techn. Commun. Commonw. Bur. Hortic. Plant Crops No. 22.

Hickey, M. G., and Kittrick, J. A. (1984). Chemical partitioning of $\mathrm{Cd}, \mathrm{Ni}$ and $\mathrm{Zn}$ in soils and sediments containing high levels of heavy metals. J. Environ. Qual. 13, 189-97.

Jarvis, S. C., and Jones, L. H. P. (1980). The contents and sorption of Cd in some agricultural soils of England and Wales. J. Soil Sci. 31, 469-79.

Kuo, S., and Baker, A. S. (1980). Sorption of copper, zinc and cadmium by some acid soils. Soil Sci. Soc. Am. Proc. 44, 969-74.

Levi-Minzi, R., Soldatini, G. F., and Riffaldi, R. (1976). Cadmium sorption by soils. J. Soil Sci. 27, 10-15.

McBride, M. B., Tyler, L. D., and Hovde, D. A. (1981). Cadmium adsorption by soils and uptake by plants. Soil Sci. Soc. Am. J. 45, 739-44.

McLaren, R. G., and Crawford, D. V. (1973). Studies on soil copper 1 The fractionation of $\mathrm{Cu}$ in soils. J. Soil Sci. 24, 172-81. 
Mann, S. S. (1989). Cadmium in fertilizers and soils. Ph.D prelim. (Thesis), The University of Western Australia.

Northcote, K. H. (1974). 'A Factual Key for the Recognition of Australian Soils.' 3rd Edn. (Rellim Technical Publications: Glenside, S.A.)

Searle, P. L., and Daly, B. K. (1977). The determination of aluminium, iron, manganese and silicon in acid oxalate soil extracts by flame emission and atomic absorption spectrometry. Geoderma 19, 1-10.

Shuman, L. M. (1985). Fractionation method for soil microelements. Soil Sci. 140, 11-22.

Simmons, W. J., and Plues-Foster, L. A. (1977). Improved methods of analysing difficult soil extracts by flame atomic absorption spectrometry. Application to measurement of $\mathrm{Cu}$ in ammonium oxalate extracts. Aust. J. Soil Res. 15, 171-75.

Soon, Y. K., and Bates, T. E. (1982). Chemical pools of $\mathrm{Cd}, \mathrm{Ni}$ and $\mathrm{Zn}$ in polluted soils and some preliminary indications of their availability to plants. J. Soil Sci. 33, 477-88.

Sposito, G., and Page, A. L. (1985). Circulation of metals in the environment. In 'Metal ions in Biological Systems. Vol. 18.' pp. 287-332. (Marcel Dekker: New York.)

Tessier, A., Campbell, P. G. C., and Bisson, M. (1979). Sequential extraction procedure for the speciation of particulate trace metals. Anal. Chem. 51, 844-51.

Tiller, K. G. (1988). Cadmium accumulation in the soil-plant system: an overview in relation to possible transfers to agricultural products. Cadmium Accumulations in Australian Agriculture. (Canberra.) Department of Primary Industries and Energy, Bureau of Rural Resources. No. 2, 20-47.

Tiller, K. G., Gerth, J., and Brummer, G. (1984). The relative affinities of Cd, Ni and $\mathrm{Zn}$ for different soil clay fractions and goethite. Geoderma 34, 17-35.

Tills, A., and Alloway, B. J. (1983). The speciation of $\mathrm{Cd}$ and $\mathrm{Pb}$ in soil solutions from polluted soils. Int. conf. on Heavy Metals in the Environment (Heidelberg).

Tyler, L. D., and McBride, M. B. (1982). Mobility and extractability of cadmium, copper, nickel and zinc in organic and mineral soil columns. Soil Sci. 134, 198-205.

Whitten, M. G., and Ritchie, G. S. P. (1991). Calcium chloride extractable Cd as an estimate of Cd uptake by subterranean clover. Aust. J. Soil Res. 29, 215-21.

Williams, C. H., and David, D. J (1973). The effect of superphosphate on the cadmium content of soils and plants. Aust. J. Soil Res. 11, 43-56.

Williams, C. H., and David, D. J. (1977). Some effects of the distribution of cadmium and phosphate in the root zone on the cadmium content of plants. Aust. J. Soil Res. 15, 59-68.

Yeomans, J. C., and Bremner, J. M. (1988). A rapid and precise method for routine determination of organic carbon in soil. Commun. Soil Sci. Plant Anal. 19, 1467-76. 